\title{
EFFECT OF PROTEIN AND VITAMIN B DEFICIENCY ON THE MORPHO-QUANTITATIVE ASPECTS OF THE MYENTERIC PLEXUS OF THE DESCENDING COLON OF ADULT RATS
}

\author{
Eduardo José de Almeida Araújo', Débora de Mello Gonçales Sant'Ana', \\ Sônia Lucy Molinari², Marcílio Hubner de Miranda Neto ${ }^{3}$
}

\begin{abstract}
We carried out this work with the purpose of studying the effects of protein and vitamin B deficiency on the morphologic and quantitative aspects of the myenteric plexus of the descending colon of adult Rattus norvegicus. Twenty-eight rats were divided in two groups, one of them receiving chow with $22 \%$ protein level (control) and the other fed with chow having $8 \%$ protein level without vitamin B supplementation, during 120 days. Whole-mounts of the descending colon were prepared and stained with Giemsa, NADHdiaphorase and NADPH-diaphorase. The undernourished rats had a body weight $11.84 \%$ less than the control group. Relative to the controls, the experimental group had a colonic area $48 \%$ smaller, $51.9 \%$ less Giemsastained neurons, $28.3 \%$ less NADH-diaphorase positive neurons and $24.2 \%$ less NADPH-diaphorase positive neurons.
\end{abstract}

KEY WORDS: enteric neurons, protein malnutrition, descending colon, vitamin B, myenteric plexus.

\begin{abstract}
Efeito da carência de proteínas e vitaminas do complexo B sobre aspectos morfoquantitativos do plexo mioentérico do colo descendente de ratos adultos

RESUMO - Realizamos este estudo com o objetivo de avaliar os efeitos da desnutrição protéica e da carência de vitaminas do complexo B sobre os aspectos morfológicos e quantitativos do plexo mioentérico do colo descendente de Rattus norvegicus adultos. Vinte e oito ratos foram divididos em dois grupos, sendo oferecida para um dos grupos ração com teor protéico de $22 \%$ (controle) e, para outro, ração com teor protéico de $8 \%$ sem suplementação de vitaminas do complexo $B$, durante 120 dias. Elaboramos os preparados de membrana do colo descendente e os coramos pelo método de Giemsa, pela técnica da NADH diaforase e da NADPH diaforase. Os ratos desnutridos apresentaram peso corporal 11,84\% menor que o grupo controle. Em relação ao controle, observou-se uma redução da área do colo do grupo experimental de $48 \%$, e de $51,9 \%$ dos neurônios corados por Giemsa, 28,3\% dos neurônios NADH-diaforase positivos e 24,2\% neurônios NADPHdiaforase.
\end{abstract}

PALAVRAS-CHAVE: neurônios entéricos, desnutrição protéica, colo descendente, vitamina B, plexo mioentérico.

The consequences of nutritional deficiencies on the intestinal morphology have interested researchers for decades ${ }^{1-6}$. Several studies demonstrated morphological alterations such as intestinal atrophy in undernourished animals $s^{1,2,5-8}$, regardless of the animals' stage of life ${ }^{2,3,6}$. The nutritional deficiencies also produce functional changes in the digestive tract, normally resulting in malabsorption and alteration of the intestinal motility ${ }^{2,3}$. Knowing that the control of motility is mainly a task of the intrinsic components of the myenteric plexus, the study of experimental malnutrition on the enteric neurons represents a fruitful area of investigation of neuronal plasticity 9 .

In what concerns the effects of undernourished on the myenteric plexus, the hypoproteic diet leads to a greater concentration of neurons $s^{5,10-12}$ and

Este trabalho é parte da dissertação de mestrado apresentada ao Programa de Pós-graduação em Biologia do Instituto de Ciências Biológicas da Universidade Federal de Goiás do primeiro autor: ' Professor da Universidade Paranaense (UNIPAR) - Umuarama PR, Brasil; ${ }^{2}$ Professora associada da Universidade Estadual de Maringá - (UEM) Maringá PR, Brasil; ${ }^{3}$ Professor titular da UEM. Apoio financeiro: UNIPAR, CAPES, UFG, UEM. 
diminishment of their numbers ${ }^{13-15}$. Nevertheless, most of the studies on the effects of malnutrition on the enteric neurons assess the small intestine ${ }^{5,8,10,13,16}$, the number of works dealing with the large intestine being reduced $^{1,11,12,14,15,17}$. Studies in the ascending colon of rats subjected to protein deficiency during gestation and lactation demonstrated increased neuronal density and incidence of large neurons ${ }^{11}$, while animals subjected to apoproteic diet during gestation and lactation had changes in the myenteric ganglia shape, reduction in the area of the neuronal profile and greater density of the neurons in the total colon ${ }^{17}$.

In the ascending colon of adult animals with protein deficiency, it was observed reduction in the total number of neurons and increase in the proportion of NADH-diaphorase positive neurons ${ }^{12}$. In the same segment of adult rats subjected to protein and vitamin deficiency, it was observed a greater reduction in the total number of myenteric neurons ${ }^{14,15}$.

In a survey of the literature, few were the authors focusing on the study of the myenteric plexus of the descending colon ${ }^{1,18}$. Studies about the action of undernourished on the myenteric plexus of the descending colon of rats were found only in models of protein-only deficiency ${ }^{19}$, demonstrating the necessity of studies on this organ. We carried out this work with the purpose of verifying the effects of the ingestion of a starch-rich, but diet poor in protein and vitamin $B$, on the neurons of the myenteric plexus of the descending colon of adult rats.

\section{METHOD}

We used 28 male Wistar rats (Rattus norvegicus) in age of 90 days old ( $299.38 \pm 27.7 \mathrm{~g}$ of body weight). The animals were handled and killed following the rules of ethic conduct in animal experimentation ${ }^{20}$. The rats were divided in two groups, control and experimental. Both were kept in individual cages with controlled temperature and light/dark cycles of $12 \mathrm{hr}$. Water was offered ad libitum. During 120 days, the control group received NUVILAB ${ }^{\circledR}$ chow with $22 \%$ protein level and the experimental group received manipulated chow with $8 \%$ protein level.

The diet of the experimental group was obtained reducing the protein levels of the NUVILAB chow through the addition of corn starch and mixture of mineral salts, but without vitamin supplementation ${ }^{14,15}$. This procedure was based on models described elsewhere ${ }^{1,5,6,12,21,22}$.

The weight of the animals was registered weekly, as it was the amount of food and water ingested. During the experimental period, we assessed features of the face and tail and the motor behavior of the animals of both groups. At the $120^{\text {th }}$ day the rats were killed through the inhalation of an excess of ethylic ether. Laparotomy was carried out and the colon was removed, its length and width measured with a millimeter rule.
The descending colon of five animals of each group was washed and filled with Krebs solution ( $\mathrm{pH} 7.3$ ), washed twice in the same solution (10 min. each) and immersed for five min in $0.3 \%$ Triton X-100 solution in Krebs. Again they were washed twice in Krebs (10 min. each) and immersed for $45 \mathrm{~min}$. to evidence of the NADH-diaphorase enzyme. This last medium contained, in $100 \mathrm{ml}: 25 \mathrm{ml}$ of Nitro Blue Tetrazolium (NBT, Sigma, St. Louis, USA) stock solution; $25 \mathrm{ml}$ phosphate buffer $0.1 \mathrm{M}, \mathrm{pH} 7.3 ; 50 \mathrm{ml}$ distilled water; and $50 \mathrm{mg}$ of b-NADH (Sigma, Steiheim, Germany) ${ }^{23}$. After incubation the segments were opened at the mesocolic border and immersed in 10\% buffered formalin solution.

The intestinal segments of other five animals of each group were washed with a $0.9 \%$ saline solution, filled and immersed in acetic formol fixative for 48 hours. Afterwards they were dissected and stained with Giemsa solution (methylene blue) in Sorensen phosphate buffer $(\mathrm{pH} 7.0)^{24}$.

The descending colon of the four remaining animals of each group was washed and filled with phosphate buffer (PB; pH 7.4), fixed in 4\% paraformaldehyde (Merck, Darmstad, Germany) prepared in PB $0.1 \mathrm{M}$ (pH 7.4) for 30 min., immersed in $0.3 \%$ Triton $\mathrm{X}-100$ dissolved in phosphate buffered saline (PBS, pH 7.4) for $10 \mathrm{~min}$. and then washed 10 times (10 min each) in PBS. Then they were immersed in the incubation medium for the neuronal evidenciation of the NADPH-diaphorase enzyme, for two $\mathrm{hr}$. This medium contained in $100 \mathrm{ml}: 25 \mathrm{mg}$ of NBT; $50 \mathrm{mg}$ of b-NADPH (Sigma, Steinheim, Germany), 03\% Triton X100 in Tris HCl buffer (GibcoBRL, New York, USA) $0.1 \mathrm{M} \mathrm{(pH}$ 6.0). After incubation the segments were opened at the mesocolic insertion, washed three times in PBS (five min each) and immersed in 5\% paraformaldehyde solution ${ }^{25}$.

The whole-mounts were dissected under stereomicroscope with trans-illumination with the removal of the mucosa and the submucosa. Next they were dehydrated in ascending series of ethylic alcohol, diaphanized in xylene and mounted between glass and coverglass with Permount synthetic resin (Fischer Chemical, New Jersey, USA).

Neuronal frequency was obtained for all the staining techniques under an Olympus BX40 microscope with a 40X objective. In each whole-mount, 40 microscopic fields were counted, half-seen neurons counted in alternate fields. The area of each microscopic field was $0.1735 \mathrm{~mm}^{2}$. This analysis was done in two regions of the intestinal circumference, the intermediate region $\left(60^{\circ}-120^{\circ}\right.$ and $\left.240^{\circ}-300^{\circ}\right)$ and the antimesocolic region $\left(120^{\circ}-240^{\circ}\right)^{12,14,15}$.

To analyze the different neuronal frequencies of a given region among the three techniques used, we used the Test of Kruskal-Wallis. We also employed the test $t$ of Student $(\alpha=5 \%)$ for collected datas to assess the differences between the neuronal frequencies of the intermediate and antimesocolic regions, considering each technique separately.

Photographic documentation was obtained with an Olympus BX50 photomicroscope and photographic equipment PM $10 \mathrm{AK}$. 


\section{RESULTS}

At the end of the experimental period, the control animals had a mean body weight of $456.03 \pm 33.48$ $\mathrm{g}$, and the experimental group $402.03 \pm 61.66 \mathrm{~g}$. The difference between the means was statistically significant $(p<0.05)$.

Table 1 presents the data on length, width and area of the descending colon of both groups. Table 2 shows the neuronal frequency of the wholemounts stained with the three techniques.

Observing the distribution of the neurons per area $\left(\mathrm{cm}^{2}\right)$, we verified in the control group 18,314 neurons $/ \mathrm{cm}^{2}$ in the intermediate region and 17,780 neurons $/ \mathrm{cm}^{2}$ in the antimesocolic region, as evaluated with the Giemsa technique (Fig 1A); for the experimental group the corresponding numbers were 16,023 neurons $/ \mathrm{cm}^{2}$ and 18,631 neurons $/ \mathrm{cm}^{2}$ (Fig 1B). Considering the NADH-diaphorase positive neurons, in the control group (Fig 2A) 7,636 neurons/ $\mathrm{cm}^{2}$ were observed in the intermediate region and 7,766 neurons $/ \mathrm{cm}^{2}$ in the antimesocolic region; in the experimental group (Fig 2B), 9,884 neurons $/ \mathrm{cm}^{2}$ were found in the intermediate region and 9,292 neurons $/ \mathrm{cm}^{2}$ in the antimesocolic region. Finally, the $\mathrm{NADPH}$-diaphorase positive neurons amounted
6,008 neurons $/ \mathrm{cm}^{2}$ in the intermediate region and 7,636 neurons $/ \mathrm{cm}^{2}$ in the antimesocolic region of the control group (Fig 3A) and 9,639 neurons $/ \mathrm{cm}^{2}$ and 8,587 neurons $/ \mathrm{cm}^{2}$, respectively, in the experimental group (Fig 3B).

\section{DISCUSSION}

In this study we evaluated the effect of reduced levels of proteins and vitamin B on the descending colon of rats. We verified that the diminishment of the protein level from $22 \%$ to $8 \%$ and the absence of vitamin supplementation did not lead to death nor to the development of diseases during the experimental period. We suggest that, even diluting the protein and vitamin B levels through the addition of corn starch, these compounds still remained in amounts sufficient to prevent clinical manifestations of malnutrition $^{14,15}$. It is known that in the pre-clinical period of undernourished biochemical alterations already exist, inducing functional and anatomical changes ${ }^{26}$.

Despite the absence of clinical signs, the diet used was effective in producing malnutrition, as indicated by the differences of body weight, size on the large intestine and, in previous studies, decrease of total blood protein and plasma albumin ${ }^{14,15}$.

Table 1. Mean of the lengths, widths and areas of the descending colon of adult rats from the control and experimental groups.

\begin{tabular}{cccc}
\hline Group & Length $(\mathrm{cm})$ & Width $(\mathrm{cm})$ & Area $\left(\mathrm{cm}^{2}\right)$ \\
\hline Control $(\mathrm{n}=14)$ & $18.34 \pm 1.0^{\mathrm{a}}$ & $1.33 \pm 0.23^{\mathrm{a}}$ & $25.0 \pm 4.45^{\mathrm{a}}$ \\
Undernourished $(\mathrm{n}=14)$ & $13.6 \pm 0.8^{\mathrm{b}}$ & $0.98 \pm 0.18^{\mathrm{a}}$ & $13.0 \pm 2.53^{\mathrm{b}}$ \\
\hline
\end{tabular}

Means followed by the same letter for each variable do not differ statistically at the level of $5 \%$. The total area of the colon was based on the measures of length and width.

Table 2. Frequency of neurons in the myenteric plexus of the descending colon of adult rats from the control and experimental groups, stained with Giemsa, NADH-diaphorase and NADPH-diaphorase in an area of $6.94 \mathrm{~mm}^{2}\left(40 \mathrm{microscopic}^{-}\right.$ fields) in the intermediate and antimesocolic regions (Mean \pm standard deviation).

\begin{tabular}{|c|c|c|c|c|c|}
\hline \multirow[t]{2}{*}{ Technique } & \multirow{2}{*}{$\begin{array}{l}\text { Number } \\
\text { of animals }\end{array}$} & \multicolumn{2}{|c|}{ Control } & \multicolumn{2}{|c|}{ Experimental } \\
\hline & & Intermediate & Antimesocolic & Intermediate & Antimesocolic \\
\hline Giemsa & 5 & $1,271 \pm 227.54$ & $1,234 \pm 225.92$ & $1,112 \pm 116.06$ & $1,293 \pm 169.19$ \\
\hline NADH-d & 5 & $530 \pm 92.97$ & $539 \pm 146.72$ & $686 \pm 235.57$ & $645 \pm 322.33$ \\
\hline NADPH-d & 4 & $417 \pm 34.42$ & $547 \pm 84.01$ A * & $669 \pm 139.30$ & $596 \pm 24.83$ \\
\hline
\end{tabular}

The differences between values in a given column are significant. The differences between values in a given line for Giemsa and NADH- $d$ are not significant. Consider $5 \%$ as the significance level. $A$, significant difference of neuronal frequency between the two regions in the control group; $\bullet$, significant differences of the neuronal frequency between the intermediate regions of the two groups; $*$ significant differences of the neuronal frequency between the antimesocolic regions of the two groups. 


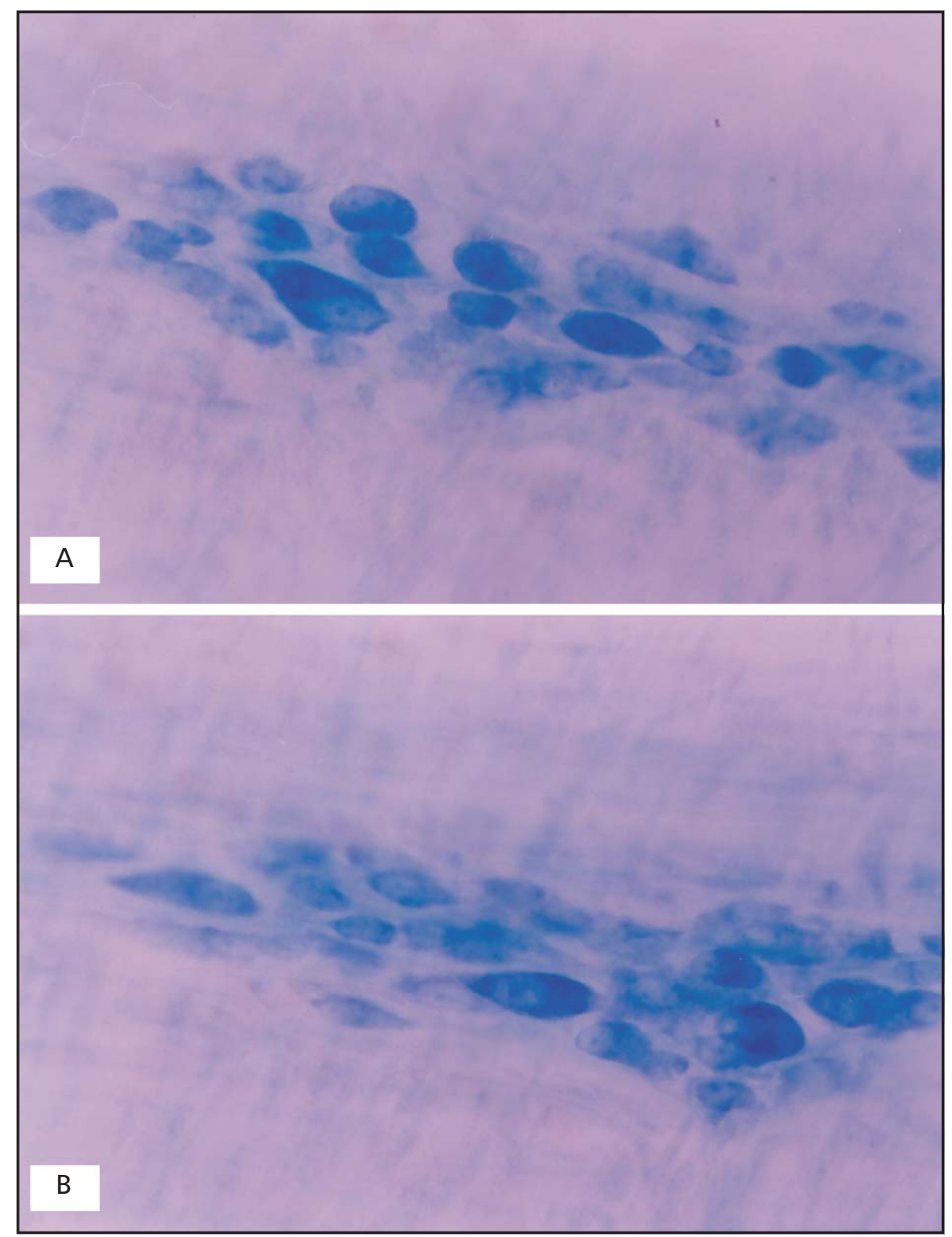

Fig 1. Whole-mount showing Giemsa-stained neurons in the myenteric plexus of the descending colon of adults rats of control group (A) and treated group (B). 408X.

The body weight gain of the animals receiving protein- and vitamin-deficient diet was significantly less, demonstrating that these biomolecules are needed in balanced amounts for the weight gain, superseding the importance of starch, which was present in excess. When comparing the body weight of the two groups, we verified that that of the undernourished rats was $11.84 \%$ smaller than that of the controls. Less body weight gain or body weight reduction was also observed in studies of protein malnutrition ${ }^{6,10,12,19,27 . ~}$

The colon of the undernourished animals had a smaller growth, leading to an area $48 \%$ smaller relative to the controls. Similar to what happened to the body mass, the reduced protein and vitamin levels may have caused a smaller development of the organ. Atrophy of the small intestine $2,3,6-8,10,16$ and of the colon ${ }^{1,12,14,15,19}$ has been a common finding of malnutrition.

The quantitative studies in the whole-mounts indicated that, regardless of the region, the number of neurons stained with Giemsa is larger than that stained either by NADH-diaphorase or NADPH-diaphorase in both groups. These data are compatible with those found in the ascending colon of rats subjected to protein undernourished with or without vitamin supplementation $^{12,14,15}$ and are due to the fact that the Giemsa stain evidences the whole neuronal population, while the NADH-diaphorase and the NADPH-diaphorase 


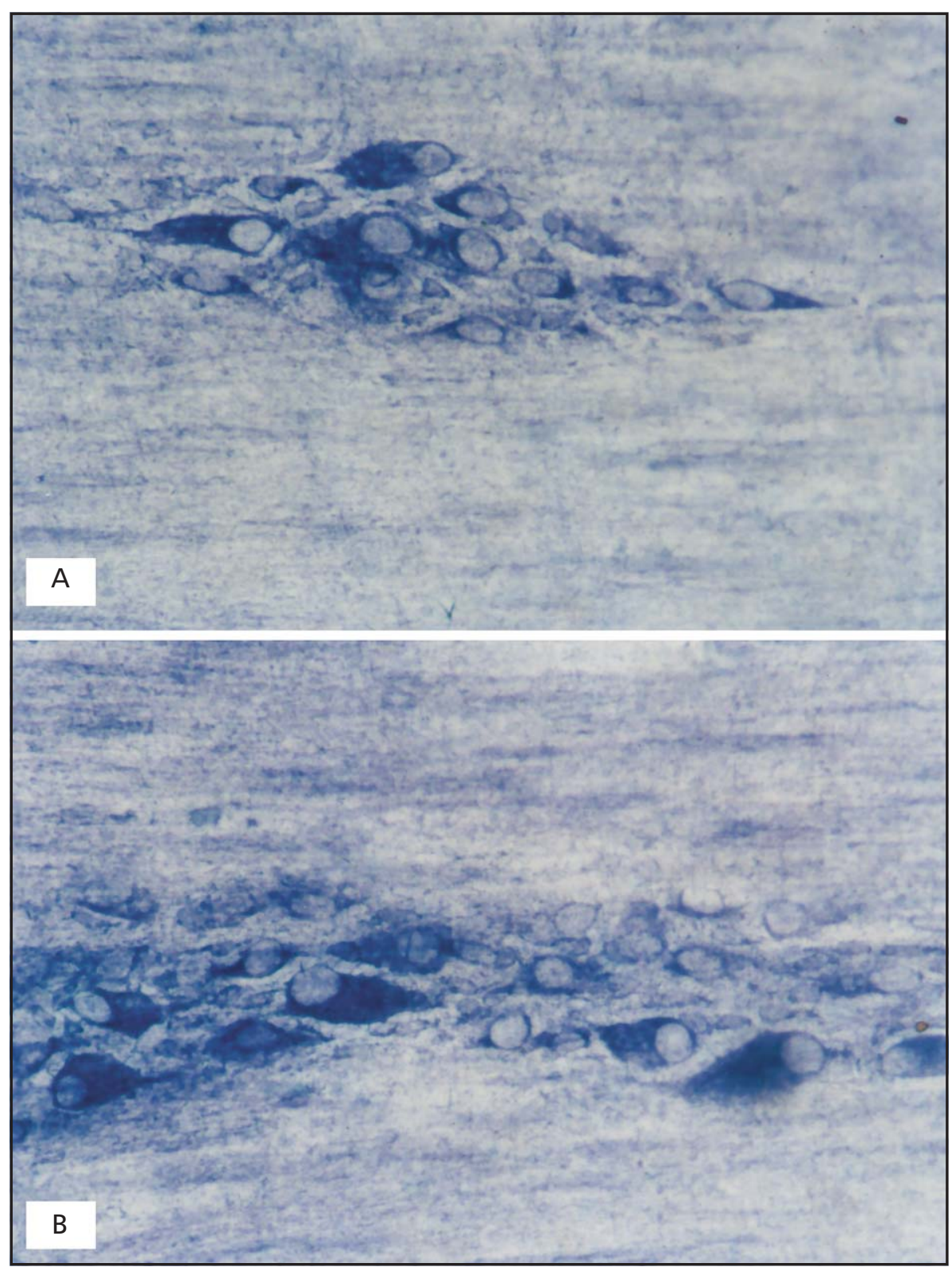

Fig 2. Whole-mount showing NADH-diaphorase positive neurons in the myenteric plexus of the descending colon of adults rats of control group (A) and treated group (B). 408X.

techniques demonstrate subpopulations of neurons

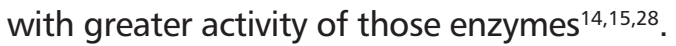

Through the analysis of our quantitative results, we found similar numbers of neurons in the control and the experimental groups, in both regions, with Giemsa and NADH-diaphorase. On the other hand, the density of NADPH-diaphorase positive neurons of the experimental group was $23.8 \%$ greater in the intermediate region and $8.2 \%$ greater in the antimesocolic region.

As there was a reduction in the colonic area (length $x$ width) of $48 \%$ in the undernourished group relative to the control, it was expected that the expe- rimental animals had a $48 \%$ greater concentration of myenteric neurons. However, there was a reduction of $3.9 \%$ of the Giemsa-stained neurons, both regions altogether. This indicated that $51.9 \%$ of the neurons were lost. In the same segment, in animals with protein deficiency, the neuronal loss was of about $40.5 \%{ }^{19}$, which demonstrated that the greater reduction observed in this study may be linked to the vitamin B deficiency. In the ascending colon of adult undernourished rats, a $27.5 \%$ loss of neurons was found when malnutrition was proteic and vitaminic $^{15}$ and $13.2 \%$ neurons were lost when malnutrition was only proteic ${ }^{12}$. In the ascending colon of rats undernourished during gestation and lactation 


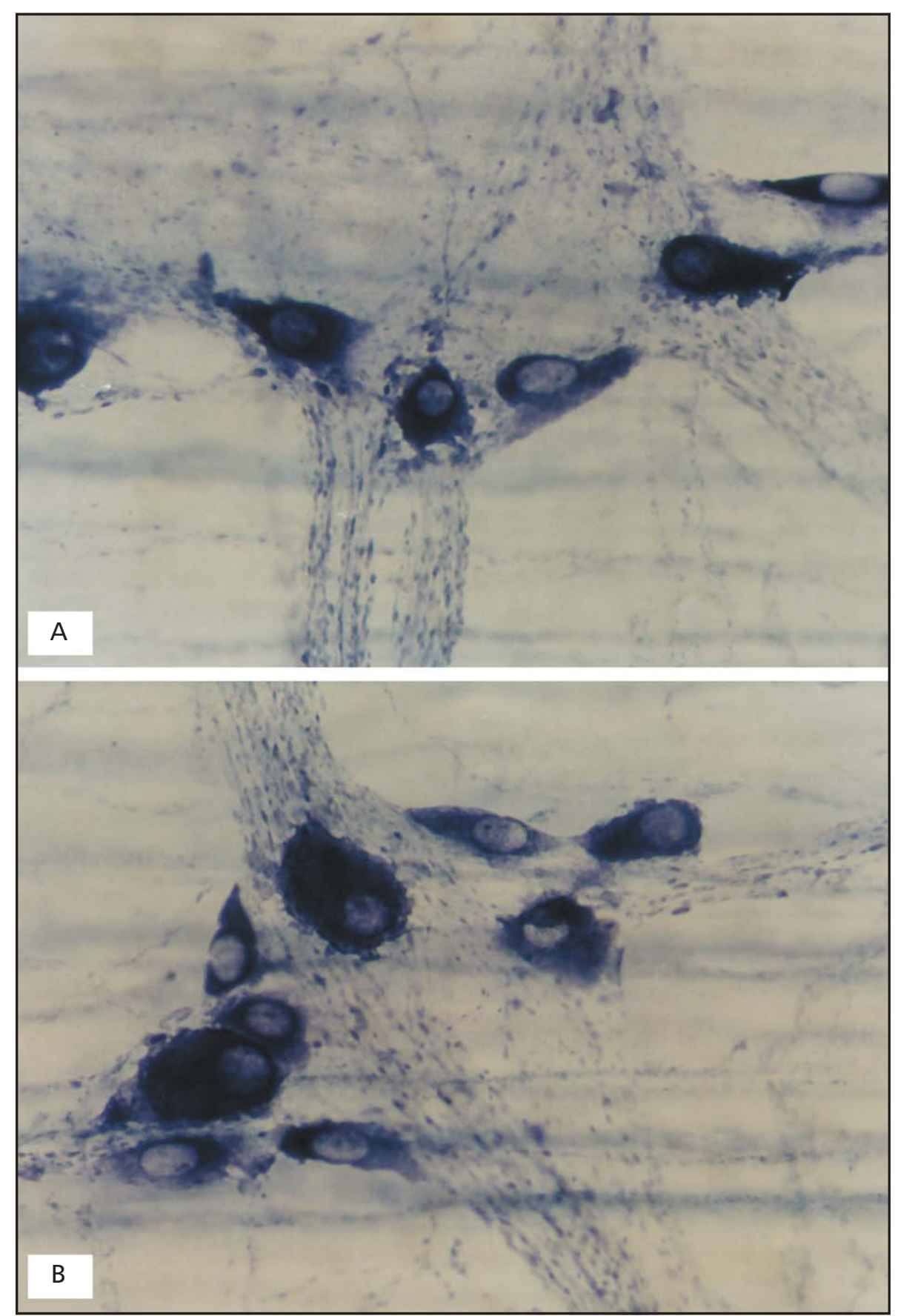

Fig 3. Whole-mount showing NADPH-diaphorase positive neurons in the myenteric plexus of the descending colon of adults rats of control group $(A)$ and treated group (B). 408X.

and normally fed until the $60^{\text {th }}$ day of age, the number of Giemsa-stained neurons did not change, despite the lack of comparison of the intestinal areas ${ }^{11}$. It is verified that the effects of malnutrition on the general number of neurons in the descending colon of rats are larger than in the ascending colon. These findings demonstrate the importance of other studies in the descending colon which could improve the knowledge of these differences and the functional changes that they bring about.
As the Giemsa technique evidences the protein synthesis machinery, and its staining intensity has been used as an indication of protein metabolism $^{5,11,12}$ we may suppose that possibly some of the $51.9 \%$ of the neurons might have had their protein synthesis reduced to the level that their staining was precluded, because of paucity of substrates and/or vitamins of the $B$ complex, which participate of this metabolic route.

As for the NADH-diaphorase positive neurons, we 
noticed a reduction of $28.3 \%$ of these neurons in the experimental group. In previous studies in the ascending colon of rats a neuronal loss of $27.2 \%$ was found in a model of protein and vitamin deficiency ${ }^{14}$ and of $0.9 \%$ in protein deficiency ${ }^{12}$. It is verified that the reductions in the subpopulation of $\mathrm{NADH}$-diaphorase positive neurons in the ascending and descending colons, when the same model of malnutrition is used, were similar, keeping in check the proportion of neurons more active metabolically in both organs.

In the colon of rats undernourished during gestation and lactation and normally fed until the $42^{\text {nd }}$ day of age, a number of NADH-diaphorase positive neurons $38 \%$ greater than that on the controls was found ${ }^{17}$. However, the area of the large intestine was $61 \%$ smaller than in the controls. It should be expected a NADH-diaphorase positive neuronal density $61 \%$ greater in the experimental group, but this figure was of $38 \%{ }^{17}$. These data indicate a loss of $23 \%$ of these neurons along the whole colon.

The comparison of our results on the NADH-diaphorase neuronal subpopulation with those of studies during the ontogenetic development demonstrated small differences: normal reduction of $28.3 \%$ in the distal colon of adult rats and of $23 \%$ during the ontogenetic development of the organ ${ }^{17}$. The difference found when ages are compared may be explained by two factors. The first is the initial stage of aging that our animals faced, once they were killed at the age of 210 days and those of Castellucci ${ }^{17}$ were killed at the age of 42 days. The reduction of the neuronal population of the large intestine was demonstrated in humans ${ }^{29}$ and rats ${ }^{13}$. The second factor could be the influence of the lack of vitamin supplementation; in this work the proportion of $\mathrm{NADH}$-diaphorase positive neurons relative to the general neuronal population (NADH-diaphorase/Gie$\mathrm{msa}$ ) in the control group was of $42.7 \%$ and in the experimental group was of $55.4 \%$. These data demonstrate that despite a reduction in the number of NADH-diaphorase positive neurons, possibly because of deficiency of vitamins of the B complex, this subpopulation increases in proportion to the general number of neurons. Perhaps neurons with less metabolic activity need to become more active to provide for the lost neurons, increasing their biochemical processes in an adaptive action, once in conditions of malnutrition the myenteric plexus works in its maximal limit to keep visceral homeostasis ${ }^{17}$.

When analyzing the subpopulation of NADPHdiaphorase positive neurons, we observed the loss of $24.2 \%$ of the neurons of the experimental group at the end of the period. On the other hand, in the ascending colon of these animals it was observed a loss of NADPH-diaphorase positive neurons of $50.5 \%$ when subjected to protein and vitamin deficiency ${ }^{15}$. When noticing the proportion of NADPH-diaphorase positive neurons relative to the total population (stained with Giemsa), we observe that in our results it was of $38.5 \%$ in the control group and $52.6 \%$ in the experimental group. Despite a reduction in the total number of NADPH-diaphorase positive neurons due to malnutrition, this is proportionately smaller than the reduction in the general population. These data differ from those found in the ascending colon, where the subpopulation of NADPH-diaphorase positive neurons was of $29.9 \%$ in the control group and of $22.8 \%$ in the experimental group ${ }^{14}$. It is observed that the effect of malnutrition on the subpopulation of nitrergic neurons is greater in the ascending than in the descending colon of rats. The increase in the proportion of nitrergic neurons indicates that these neurons were lost in smaller amounts than other subpopulations. Considering that the proportion of nitrergic neurons of the descending colon of the control group is necessary for the balance between contraction and relaxation so as to provide for fecal propulsion, it was observed that this experimental model altered this balance. The accumulation of inhibitory neurons, which increase from $38 \%$ to $52.6 \%$, may compromise the motility of the descending colon. An intense relaxation, together with the possibility of less contraction force could impair evacuation, leading to chronic constipation. Electrophysiologic studies must be done to assess this hypotesis. These data agree with the information that the study of malnutrition on the enteric neurons is a promising field.

In summary, the present study demonstrated that the reduction in the protein level of the diet to $8 \%$ together with the reduction in the vitamin B level of the diet of adult rats led to decreased body weight and area of the descending colon, as well as a decrease in the total number of myenteric neurons and less staining of the NADH-diaphorase and NADPHdiaphorase positive neuronal subpopulations.

\section{REFERENCES}

1. Araújo EJA. Estudo morfológico e quantitativo dos neurônios do plexo mioentérico do colo descendente de ratos normoalimentados e submetidos à carência de proteínas e vitaminas do complexo B. Dissertação de Mestrado, Universidade Federal de Goiás. Goiânia, 2002.

2. Takano J. Intestinal changes in protein-deficient rats. Exp Mol Pathol 1964;3:224-231.

3. Hill RB, Prosper J, Hirschfield JS, Kern F. Protein starvation and the small intestine: I. The growth and morphology of small intestine in weanling rats. Exp Mol Pathol 1968;8:66-74. 
4. Maffei HVL, Rodrigues MAM, Camargo JLV, Campana AO. Intraepithelial lymphocytes in jejunal mucosa of malnourished rats. Gut 1980;21:32-36.

5. Natali MRM, Miranda-Neto MH. Effect of maternal protein deprivation on morphological and quantitative aspects of the myenteric plexus neurons of proximal colon in rats. Arq Neuropsiquiatr 1996;54:273-279.

6. Natali MRM, Miranda-Neto MH, Orsi AM. Effects of hypoproteic diet supply on adult Wistar rats (Rattus norvegicus). Acta Scientiarum 2000;22:567-571.

7. Firmansyah A, Suwandito L, Penn D, Lebenthal E. Biochemical and morphological changes in the digestive tract of rats after prenatal and postnatal malnutrition. Am J Clin Nutr 1989;50:261-268.

8. Brandão MCSB. Análise morfoquantitativa do plexo mioentérico do intestino delgado de ratos jovens submetidos à desnutrição protéica pré e pós natal. Dissertação de mestrado, Universidade de São Paulo. São Paulo-SP, 1998.

9. Furness JB, Costa M. The enteric nervous system. Edinburg: Churchill Livingstone, 1987.

10. Torrejais MM, Natali MRM, Conegero CI, Miranda-Neto MH. Effect of protein malnutrition after breast-feeding on the morphology of the intestinal wall and myenteric neurons of the ileum rats. Rev Unimar 1995;17:315-327.

11. Mello EVSL, Stabille SR, Miranda-Neto MH. Effect of maternal protein deprivation on morphological and quantitative aspects of the myenteric plexus neurons of proximal colon in rats. Arq Neuropsiquiatr 1995;55:106-113.

12. Sant'Ana DMG, Miranda-Neto MH, Souza RR, Molinari SL. Morphological and quantitative study of the myenteric plexus of the ascending colon of rats subjected to proteic desnutrition. Arq Neuropsiquiatr 1997;55:687-695.

13. Santer RM, Baker DM. Enteric neuron numbers and sizes in Auerbach's plexus in the small and large intestine of adult and aged rats. J Auton Nerv Syst 1988;28:59-67.

14. Sant'Ana DMG, Molinari SL, Miranda-Neto MH. Effects of protein and vitamin B deficiency on blood parameters and myenteric neurons of the colon of rats. Arq Neuropsiquiatr 2001;59:493-498.

15. Sant'Ana DMG. Efeitos da deficiência de proteínas e vitaminas do complexo B sobre parâmetros sangüíneos e aspectos metabólicos e morfoquantitativos dos neurônios do plexo mioentérico do colo ascendente de ratos adultos. Tese, Universidade Estadual de Maringá. Maringá, 2001.
16. Natali MRM. Estudo morfoquantitativo e ultra-estrutural do plexo mientérico do duodeno de ratos (Rattus norvegicus) adultos submetidos a carência protéica. Tese, Universidade Estadual Paulista. Botucatu, 1999

17. Castelucci P. Análise morfoquantitativa do plexo mientérico do intestino grosso de ratos submetidos à desnutrição protéica pré e pós natal e à renutrição pós-natal. Tese; Universidade de São Paulo. São Paulo 1999.

18. Christensen J, Stiles MJ, Rick GA, Sutherland J. Comparative anatomy of the myenteric plexus of the distal colon in eight mammals. Gastroenterology 1984;86:706-713.

19. Recinos JGL. Estudo quantitativo do plexo mientérico do colo descendente de ratos submetidos à desnutrição protéica. Monografia, Universidade Estadual de Maringá. Maringá 1996.

20. Brasil, Lei n. 6.638, de 8 de maio de 1979 . Normas para a prática didático-científica da vivissecção de animais e determinação de outras providências. Lex 1979;43:416.

21. Moura AS. Estudo em ratos do processo de adaptação a dietas com níveis variados de proteínas com e sem restrição energética. Tese, Universidade de São Paulo, São Paulo,1994.

22. Lepri ER, Bruschii LC, Moura AS. Efeitos da desnutrição protéica durante os períodos pré e pós natal no desenvolvimento cerebelar. Rev Bras Ciênc Morf 1994;11:22-27.

23. Gabella G. Detection of nerve cells by histochemical technique. Experientia 1969;25:218-219.

24. Barbosa AJA. Técnica histológica para gânglios nervosos intramurais em preparados espessos. Rev Bras Pesq Med Biol 1978;11:95-97.

25. Scherer-Singler U, Vincent SR, Kimura H, McGeer EG. Demonstration of a unique population of neurons with NADPH-diaphorase histochemistry. J. Neurosci Methods 1983;9:229-234.

26. Nobrega FJ. Distúrbios da desnutrição. Rio de Janeiro: Revinter,1996:4594;188-278.

27. Meilus M, Natali MRM, Miranda-Neto MH. Study of the myenteric plexus of the ileum of rats subjected to protein undernutrition. Rev Chil Anat 1998;16:9-14.

28. Miranda-Neto MH, Molinari SL, Natali MRM, Sant'Ana DMG. Regional differences in the number and type of myenteric neurons of the ileum of rats. Arq Neuropsiquiatr 2001;59:54-59.

29. Gomes AO, Souza RR, Liberti EA. A Preliminary investigation of the effects of aging on the nerve cell number in the myenteric ganglia of the human colon. Gerontology 1997;43:210-217. 